\title{
THE IMPACT OF THE COVID-19 PANDEMIC ON TOURISM
}

DOI: https://doi.org/10.18509/GBP210147d

UDC: 338.48]:616.98:578.834\}-036.21(497.11)

338.48]:616.98:578.834\}-036.21(497.5)

\author{
Aleksandra Dragin ${ }^{1}$ \\ Maja Mijatov ${ }^{1}$ \\ Zrinka Zadel ${ }^{2}$ \\ Kristina Košić1 \\ Tatjana Pivac ${ }^{1}$ \\ ${ }^{1}$ University of Novi Sad, Faculty of Sciences, Trg Dositeja Obradovića 3, Novi Sad, Serbia \\ ${ }^{2}$ University of Rijeka, Faculty of Tourism and Hospitality Management, Primorska 42, Opatija, \\ Croatia
}

\begin{abstract}
Specific challenges for overall tourism industry were evident during the SARS outbreak, mainly due to the fact that majority of tourists cancelled or postponed their travels. Accordingly, previous research indicated that understanding the impact of unexpected crises and risks is essential for tourism recovery. The fact that COVID-19 is prone to global expansion increased the fear of travelling, which additionally supported the previously mentioned claim. Uncertainty on whether or not the crisis is over, and whether or not it will repeat anywhere in the world, could affect tourists' and managers' perception of the virus as a serious threat. This research will analyse changes in tourism trends, on global as well as national and local levels in Serbia. Also, through conversations with various stakeholders, their perceptions of the impact of the pandemic on tourism will be determined. The research results will support and provide findings needed for managerial actions aimed at tourism recovery and adjustment to this unique situation.
\end{abstract}

Keywords: COVID-19, tourism, world, Serbia, Croatia.

\section{INTRODUCTION}

In terms of the economy, tourism became one of the world's most growing and dynamic sectors during the previous decades. Importance of this sector is evident, mainly according to the fact that it represents a significant trigger for creating the new job positions, especially for women and young members of the society, as well as for encouraging the economic development and promoting the local culture and products [1]. On the other hand, it is also important to indicate that tourism is a sensitive economic branch, affected by various global crises throughout the recent historical events (Table $1)$. 
Table 1: Tourism and the global crisis - Summary of indicators on the previous crises

\begin{tabular}{|l|l|l|l|}
\hline Crisis Year & $\begin{array}{l}\text { Sept } 11^{\text {th }} \\
\text { attacks } \\
2001\end{array}$ & $\begin{array}{l}\text { SARS } \\
2003\end{array}$ & $\begin{array}{l}\text { Global econ. } \\
\text { crisis } \\
2009\end{array}$ \\
\hline World arrivals (\% change) & $+0.1 \%$ & $-0.4 \%$ & $-4.0 \%$ \\
\hline Month o (zero) & Sept. 2001 & March 2003 & Jan. 2009 \\
\hline N. of months for growth recovery & 5 & 5 & 10 \\
\hline N. of months for returning to the previous volumes & 14 & 11 & 19 \\
\hline World receipts (real change, \%) & $-2.0 \%$ & $-1.7 \%$ & $-5.4 \%$ \\
\hline Most impacted region & Americas & Asia Pacific & Europe \\
\hline Region's arrivals (\% change) & $\mathbf{- 5 . 9 \%}$ & $\mathbf{- 9 . 4 \%}$ & $\mathbf{- 5 . 3 \%}$ \\
\hline N. of months for growth recovery & 12 & 7 & 14 \\
\hline N. of months for returning to the previous volumes & 42 & 14 & 29 \\
\hline Region's receipts (real change, \%) & $-11.1 \%$ & $-8.1 \%$ & $-6.7 \%$ \\
\hline
\end{tabular}

Source: [2]

However, neither one of the previously mentioned crisis did not cause such a strong impact on tourism as the last one - COVID-19 pandemic, which suddenly caused a total collapse in this sector, with still unpredictable effects and consequences on the global health, social and economic issues (Figure 1 and 2).

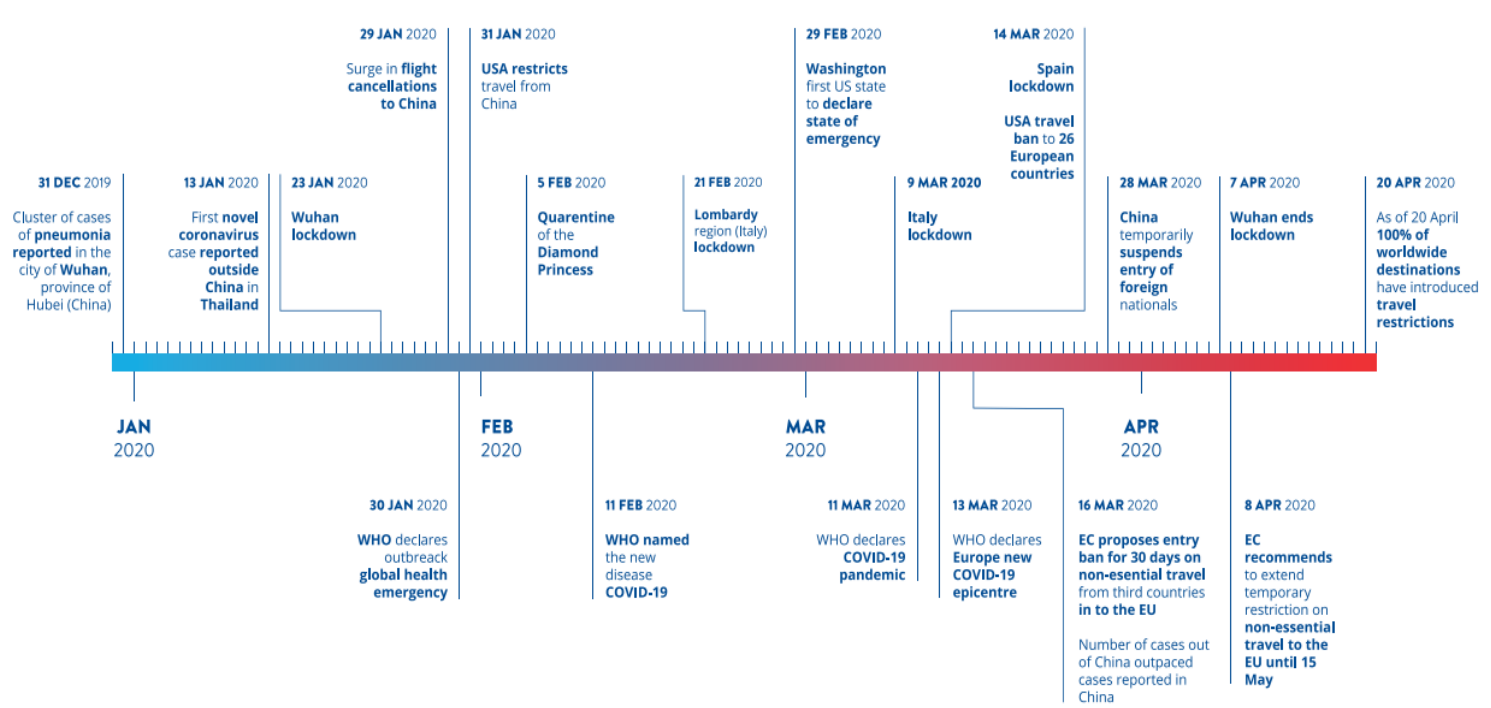

Figure 1: Timeline of important events during the COVID-19 pandemic Source: [2]

Different organizations, operating in the field of tourism and hospitality, reopened their business units, after needful closure (between March and June 2020). However, reopened business units had to implement a set of health and sanitary measures, that often required changes in terms of allowed number of people in the same place at the same time, cleaning and disinfection measures of public and private areas more often during a day, prohibition of self-service in areas with food, as well as measures related to a mandatory wearing of masks for both, employees on the one hand, and tourists on the other [3]. Immediately became clear that such measures will be required as long as the virus is active (Graph 1). 


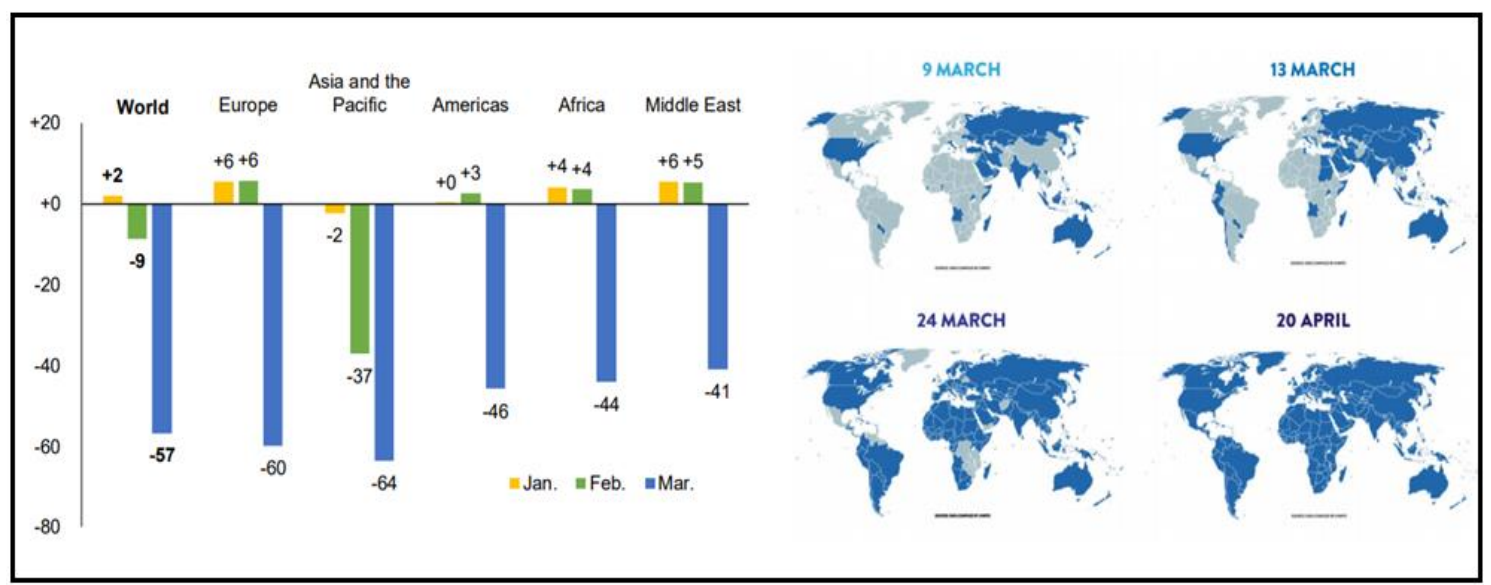

Figure 2: Changes in international tourist arrivals in March 2020 (represented in percentages) - left; Travel restrictions evaluation - right. Source: [2]

Since April 2020, 115 of worldwide destinations responded to the global crisis situation, by introducing the travel restrictions (Figure 1 and 2):

- 97 destinations out of the total 115 destinations worldwide, totally or partially closed their borders for tourists;

- $30 \%$ of destinations, which represent 65 destinations out of the total sample, totally or partially suspended their openness to international flights;

- $18 \%$ of the worldwide destinations, 39 destinations out of the total sample, implemented the closure of borders for tourists from concrete countries [2].

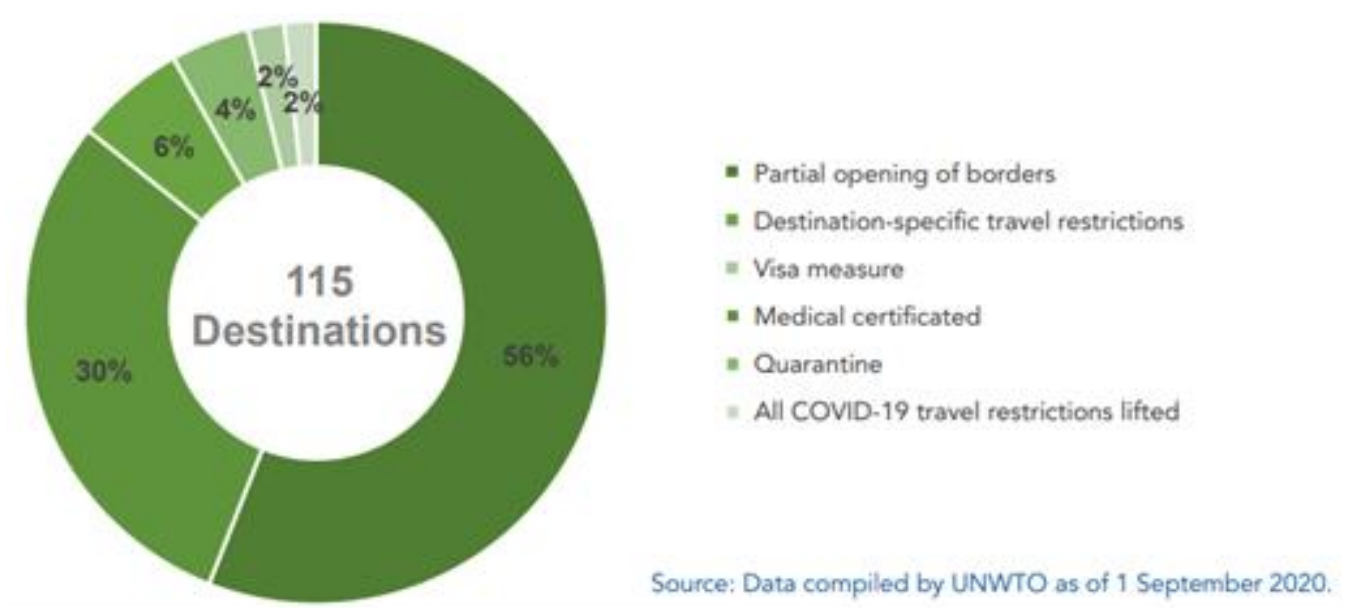

Graph 1: Type of the travel restrictions during the COVID-19 pandemic Source: [4]

UNWTO indicated that COVID-19 pandemic caused unprecedented health, social and economic emergency condition in global terms. Tourism sector represents one of the most affected sectors, as evidenced by a recorded decrease in international arrivals, as well as by implemented travel restrictions worldwide, which returned indicators of performances for this sector, back to the levels recorded even 30 years ago [5]. Indicators of financial losses in tourism pointed to the fact that international tourism arrivals during the 2020 decreased for almost 1 billion arrivals, while international tourism receipts decreased for 1.1 trillion USD. On the other hand, global GDP, decreased for 2 trillion of USD, which is more than $2 \%$ of the global GDP recorded in 2019. It is expected that implementation of the vaccine will progressively lead to returning the travelers' confidence, as well to reduction of established travel restrictions [5], [6]. 
In a short time, several studies have been conducted on the impact of the pandemic on tourism around the globe [7], [8], [9], [10], [11], [12], [3], [13], [14], [15]. However, it is important to indicate that Spain was in focus of several researches, according to pronounced negative indicators of COVID-19 statistics [13], [14], [16]. Having in mind that numerous countries and regions were also affected, it is important to investigate the possible differences in wide range of other countries. In respect to that, this paper will be focused on researching the impact of the COVID-19 pandemic on tourists' arrivals around the world, as well as on a particular example of tourism in Serbia.

\section{METHODOLOGY}

With the purpose of analyzing the impact of the COVID-19 pandemic on global and Serbian tourism market, quantitative and qualitative analysis methods were used in order to evaluate a different kind of data. Structured or semi-structured texts were obtained from the following sources: official documents, websites, survey, interviews.

Our first step was to analyze the changes in demand, in terms of tourism arrivals around the globe (in total and by regions), in Europe, in Croatia, as well as in Serbia, in 2020. Croatia was taken as a case study, because it is a neighbouring country of Serbia, while, at the same time, it represents a country with highly developed tourism. The basic process of data collecting was based on official data (World Tourism Organization, International Labor Organization, Organization for Economic Cooperation and Development, Ministry of Tourism and Sport of the Republic of Croatia, Croatian Bureau of Statistics, Statistical Office of the Republic of Serbia, Ministry of Trade, Tourism, and Telecommunications of Serbia).

Second stage of the research puts a focus on the local people in Serbia in order to investigate their intention to travel or to cancel a previously planned trip. For this purpose, data were collected by a survey research. The research was conducted during the main tourism season in the time of the COVID-19 pandemic crisis 2020 and in the year of preparation of the European Capital of Culture - Novi Sad 2021. Data were gathered from the sample of 142 Tourism and Hospitality management students of the Faculty of Science, University of Novi Sad (Republic of Serbia). However, sixteen participants were excluded because they had more than 5\% of missing data, which means that 126 respondents completely filled out the questionnaire. They were both genders, with $60.3 \%$ of females and $39.7 \%$ of males, aged between 18 and 22 years. It is also important to indicate that Novi Sad was declared the Youth Capital in 2019 and majority of the respondents were involved in accompanied voluntarily activities. Numerous events and other activities that were planned upon the both titles were postponed, canceled, or even realized in the other form.

Data were collected by a questionnaire designed for the purpose of this research. The questionnaire was conducted on students in their classrooms on several occasions during the period from June to October of 2020. Students were previously informed on research objectives and asked to fill out the questionnaire during ten minutes of their class time. The research was anonymous and the respondents were informed on the fact that research results will be used in scientific purpose only.

This construct was measured by the questionnaire UPlanP (Dragin, Majstorović \& Janičić, 2020) with 15 initial items (Table 2) and Likert's type rating scale, ranging from 1 to 5, with following meaning: 1 - "There were no activities related to planning the travel", 2 - "I have booked a trip", 3 - "I canceled the reservation", 4 - "I booked a trip again (new)", 5 - "I have canceled each trip". 
Table 2: Intention to travel or not: Timeline of important events during the COVID-19 pandemic (critical points for making a travel decision)

\begin{tabular}{|l|}
\hline Before the first registered case of the corona virus in China \\
\hline The first case of the corona virus was registered in China \\
\hline The first case of the corona virus was registered outside the China's borders \\
\hline The first case of the corona virus was registered in Europe \\
\hline The first case of the corona virus was registered in Italy \\
\hline Lockdown in Italy (Lombardy Region) \\
\hline The first case of the corona virus was registered in Serbia \\
\hline Number of the corona virus cases increased in Serbia \\
\hline The first case of the corona virus was registered in my place of living \\
\hline Quarantine measures have been implemented in Serbia due to the COVID-19 spreading \\
\hline Number of the corona virus cases decreased in Serbia \\
\hline Quarantine measures in Serbia have been canceled \\
\hline $\begin{array}{l}\text { Encouraging information might be found in media, e.g. that the virus is weakening due to the favorable } \\
\text { weather conditions, as well as due to its mutation }\end{array}$ \\
\hline Media published the information regarding the fact that number of infected people is growing again \\
\hline I found better prices for travel arrangements due to the COVID-19 pandemic \\
UPlanP by Dragin, Majstorović and Janičić, 2020
\end{tabular}

During the first phase of the research, three hypotheses were determined:

H1: Number of the travel reservations increased in the later stages of the COVID-19 pandemic, comparing to the starting phase, when the first case of the corona virus was registered in China.

$\mathrm{H} 2$ : Number of the travel cancelations sharply decreased in the later stages of the COVID19 pandemic, comparing to the phase when the first case of the corona virus was registered in Serbia.

H3: Publishing of the encouraging information in media, e.g. that the virus is weakening additionally increased the number of travel reservation.

The third stage of the research concerned managers employed in tourism sector in Serbia. For this purpose, interviews were conducted from September 2020 to February 2021. Questions for the interview were also designed for the purpose of this research. The sample included employees from 130 different type organizations that are operating in tourism sector in Serbia, including 15 cities, 5 rural settlements and 4 mountain centers. Total sample gathered employees from 69 travel agencies, 39 accommodation establishments (hotel, motel etc.), 10 museums/galleries and 12 local tourism organizations as well.

The following questions were asked:

- Whether the COVID-19 pandemic affected tourism in your local area?

- Whether the number of tourist arrivals in your business unit has changed due to the COVID-19 pandemic?

- Did you take certain measures to motivate tourists to visit your business unit during the COVID-19 pandemic?

- Are some services/facilities now perceived as more attractive for tourists during their last visit, comparing to their perception of the same services/facilities before the COVID-19 pandemic?

- Did you notice changes in the behavior of tourists who have visited your business unit during the COVID-19 pandemic, comparing to their behavior before the COVID-19 pandemic?

- How should your local community prepare the business activities for the next tourist season? 
- In your opinion, what would be the most effective measures of your business unit for the next tourist season due to the COVID-19 pandemic?

\section{RESULTS}

UNWTO lunched a tool called Tourism Recovery Tracker. This Tracker indicated results that are not encouraging at all. Comparing to the same month of the previous year in the world / Europe, data indicated the following results

- Short-term rentals (December): $-7 \% /-8 \%$,

- Occupancy rates (December): $-14 \% /-20 \%$,

- Hotel booking (January): $-54 \% /-54 \%$,

- Hotel searchers (January): - 55\% / -55\%,

- Seat capacity - domestic (December): $-61 \% /-63 \%$,

- Seat capacity - International (December): $-73 \% /-73 \%$,

- International tourist arrivals (December): $-74 \% /-71 \%$,

- Actual air reservations (January): $-90 \% /-93 \%$ [6].

Table 3: International tourism arrivals in 2020 (comparing to the same month of the previous year)

\begin{tabular}{|c|c|c|c|c|c|c|c|c|c|c|c|c|c|}
\hline Region & Jan & Feb & Mar & Apr & May & Jun & Jul & Aug & Sep & Oct & Nov & Dec & YTD \\
\hline Africa & 0 & -1 & -36 & -90 & -90 & -91 & -89 & -85 & -84 & -83 & -82 & -80 & -70 \\
\hline North Africa & 4 & 3 & -57 & -97 & -99 & -98 & -93 & -89 & -88 & -90 & -91 & -85 & -78 \\
\hline $\begin{array}{l}\text { Sub-Saharan } \\
\text { Africa }\end{array}$ & -1 & -4 & -26 & -86 & -85 & -85 & -84 & -83 & -82 & -79 & -78 & -78 & -64 \\
\hline Americas & 0 & 3 & -50 & -94 & -93 & -92 & -88 & -97 & -83 & -80 & -78 & -71 & -69 \\
\hline Caribbean & -6 & -2 & -58 & -99 & -98 & -93 & -80 & -81 & -81 & -77 & -76 & -70 & -67 \\
\hline $\begin{array}{l}\text { Central } \\
\text { America }\end{array}$ & -3 & 7 & -55 & -97 & -99 & -99 & -99 & -99 & -99 & -97 & -92 & -87 & -74 \\
\hline North America & 4 & 4 & -45 & -91 & -90 & -90 & -87 & -86 & -79 & -76 & -72 & -64 & -67 \\
\hline South America & -5 & -3 & -59 & -99 & -100 & -99 & -98 & -98 & -98 & -95 & -95 & -91 & -73 \\
\hline $\begin{array}{l}\text { Asia and } \\
\text { Pacific }\end{array}$ & -9 & -54 & -82 & -98 & -99 & -98 & -95 & -95 & -96 & -96 & -95 & -95 & -84 \\
\hline $\begin{array}{l}\text { North-East } \\
\text { Asia }\end{array}$ & -19 & -80 & -94 & -99 & -99 & -98 & -97 & -96 & -94 & -93 & -93 & -93 & -88 \\
\hline Oceania & 6 & -20 & -60 & -99 & -99 & -99 & -99 & -99 & -98 & -98 & -98 & -99 & -79 \\
\hline South Asia & -15 & -26 & -73 & -99 & -99 & -95 & -75 & -75 & -95 & -97 & -93 & -92 & -77 \\
\hline $\begin{array}{l}\text { South-East } \\
\text { Asia }\end{array}$ & 2 & -37 & -71 & -95 & -95 & -98 & -98 & -98 & -98 & -98 & -98 & -98 & -82 \\
\hline Europe & 5 & 2 & -61 & -98 & -96 & -88 & -71 & -67 & -72 & -77 & -87 & -85 & -71 \\
\hline $\begin{array}{l}\text { Central/East } \\
\text { Europe }\end{array}$ & -1 & -5 & -44 & -98 & -97 & -91 & -77 & -77 & -79 & -81 & -83 & -80 & -72 \\
\hline $\begin{array}{l}\text { Northern } \\
\text { Europe }\end{array}$ & 5 & 4 & -57 & -97 & -96 & -93 & -83 & -79 & -82 & -84 & -91 & -93 & -75 \\
\hline $\begin{array}{l}\text { Southern/Med. } \\
\text { Eur. }\end{array}$ & 6 & 1 & -69 & -97 & -96 & -89 & -73 & -66 & -69 & -73 & -86 & -83 & -72 \\
\hline $\begin{array}{l}\text { Western } \\
\text { Europe }\end{array}$ & 8 & 6 & -64 & -98 & -96 & -83 & -60 & -58 & -67 & -79 & -91 & -88 & -67 \\
\hline Middle East & 6 & -1 & -68 & -99 & -99 & -99 & -94 & -93 & -91 & -88 & -87 & -90 & -76 \\
\hline Middle East & 6 & -1 & -68 & -99 & -99 & -99 & -94 & -93 & -91 & -88 & -87 & -90 & -76 \\
\hline World & -1 & -16 & -64 & -97 & -96 & -91 & -80 & -77 & -79 & -83 & -88 & -85 & -74 \\
\hline
\end{tabular}

Sources: [6]

Destinations that are mainly focused on international tourism, especially those oriented towards business and events as the main aspects of their selective types of tourism, were mainly affected, while situation in destinations that are located in coastal and rural areas, 
for example, showed better results, comparing to the city destinations [17]. It is important to indicate that several large are a seven showed some signs of recovery in the last few months [5] (Table 3 and 4).

Expectations related to tourism recovery are indicating to the fact that domestic tourism will faster gain better results, comparing to the international tourism [1]. In that manner, domestic tourism will continue to grow in several large markets, including China and Russia, where domestic air travel demands even returned to the levels registered before the occurrence of the COVID-19 pandemic [5]. However, recovery of domestic tourism in other (smaller) markets could not be considered as a compensation for a decrease in international demand [5].

Table 4: International tourism arrivals in 2020 (comparing to the same month of the previous year). Top 10 destinations, world and Serbia

\begin{tabular}{|l|l|l|l|l|l|l|l|l|l|l|l|l|l|}
\multicolumn{10}{c|}{ month of the previous year). Top 10 destinations, world and Serbia } \\
\hline Destinations & Jan & Feb & Mar & Apr & May & Jun & Jul & Aug & Sep & Oct & Nov & Dec & YTD \\
\hline China & -18 & -92 & -94 & -99 & -98 & -97 & -94 & -92 & -91 & -92 & -91 & & -89 \\
\hline France & & & & & & & & & & & & & \\
\hline Germany & 2 & 1 & -71 & -97 & -95 & -83 & -62 & -60 & -63 & -77 & -92 & & -69 \\
\hline Italy & 4 & -8 & -83 & -90 & -84 & -72 & -55 & -45 & -47 & -66 & & & -63 \\
\hline Mexico & 9 & 12 & -34 & -79 & -74 & -75 & -67 & -62 & -40 & -44 & -46 & & -52 \\
\hline Spain & -1 & 1 & -64 & - & -100 & -98 & -75 & -76 & -87 & -87 & -90 & & -78 \\
& & & & 100 & & & & & & & & & \\
\hline Thailand & 2 & -43 & -76 & - & -100 & - & - & - & - & - & - & - & -83 \\
& & & & 100 & & 100 & 100 & 100 & 100 & 100 & 100 & 100 & \\
\hline Turkey & 16 & 4 & -68 & -99 & -99 & -96 & -86 & -71 & -59 & -59 & -61 & & -73 \\
\hline UK & 7 & 6 & -54 & -97 & -96 & -95 & & & & & & & -82 \\
\hline USA & 0 & -1 & -49 & -96 & -96 & -95 & -93 & -91 & -91 & -89 & 85 & & -77 \\
\hline World & -1 & -16 & -64 & -97 & -96 & -91 & -80 & -77 & -79 & -83 & -88 & -85 & -74 \\
\hline Serbia & 28 & 19 & -58 & -96 & -94 & -85 & -85 & -84 & -76 & -66 & -68 & -76 & -68 \\
\hline Croatia & 6 & 5 & -77 & - & -96 & -73 & -48 & -48 & -78 & -83 & -78 & -83 & -64 \\
& & & & 100 & & & & & & & & & \\
\hline
\end{tabular}

Sources: [6], [18], [19]

Analysis of official data pointed out that tourist arrivals in Croatia suddenly decreased in 2020, as a consequence of the COVID-19 pandemic (Tables 4 and 5). Comparing to 2019, data showed the following results:

- The most affected months were April and May ${ }^{1}$ (Table 4), the same as around the globe (Table 3 and 4). Equal situation is with overnight stays.

- Decrease in tourist arrivals in Croatia in 2020 (Table 5): 55.3\% (23.7\% of domestic, $58.0 \%$ of foreign tourists);

- Decrease in tourist overnight stays in Croatia in 2020 (Table 5): 64.2\% (34.2\% of domestic, $68.0 \%$ of foreign tourists

\footnotetext{
${ }^{1}$ The first case of the COVID-19 in Croatia was registered on February 25, 2020 [20].
} 
Table 5: Tourists arrivals and overnight stays: domestic and foreign - annual data

\begin{tabular}{|c|c|c|c|c|c|c|c|c|}
\hline \multirow[t]{2}{*}{ Year } & \multicolumn{6}{|c|}{ Tourists arrivals } & \multicolumn{2}{|c|}{$\begin{array}{l}\text { Participation in the } \\
\text { total number of } \\
\text { arrivals in Croatia } \\
\text { (in \%) }\end{array}$} \\
\hline & Total & Index* & Domestic & Index* & Foreign & Index* & Domestic & Foreign \\
\hline 2016 & $15,463,160$ & 107,8 & $1,748,590$ & 105,3 & $13,714,570$ & 108,1 & 11.3 & 88.7 \\
\hline 2017 & $17,430,580$ & 112,7 & $1,837,681$ & 105,1 & $15.592,899$ & 113,7 & 10.5 & 89.5 \\
\hline 2018 & $18,666,000$ & 107,1 & $2,021,000$ & 110,0 & $16,645,000$ & 106,7 & 10.8 & 89.2 \\
\hline 2019 & $19,566,146$ & 104,8 & $2,212,658$ & 109,5 & $17,353,488$ & 104,3 & 11.3 & 88.7 \\
\hline 2020 & $7,001,128$ & 35,8 & $1,455,849$ & 65,8 & $5,545,279$ & 32,0 & 20.8 & 79.2 \\
\hline \multirow[t]{2}{*}{ Year } & \multicolumn{6}{|c|}{ Tourists overnight stays } & \multicolumn{2}{|c|}{$\begin{array}{l}\text { Participation in the } \\
\text { total number of } \\
\text { overnight stays in } \\
\text { Croatia (in \%) }\end{array}$} \\
\hline & Total & Index* & Domestic & Index* & Foreign & Index* & Domestic & Foreign \\
\hline 2016 & $77,918,855$ & 108.8 & $5,819,465$ & 101.3 & $72,099,390$ & 109.5 & 7.5 & 92.5 \\
\hline 2017 & $86,200,261$ & 110.6 & $5,978,264$ & 102.7 & $80,221,997$ & 111.3 & 6.9 & 93.1 \\
\hline 2018 & $89,651,000$ & 104.0 & $6,476,000$ & 108.3 & $83,175,000$ & 103.7 & 7.2 & 92.8 \\
\hline 2019 & $91,242,931$ & 101.8 & $7,095,300$ & 109.6 & $84,147,631$ & 101.2 & 7.8 & 92.2 \\
\hline 2020 & $40,794,455$ & 44.7 & $5,415,391$ & 76.3 & $35,379,064$ & 42.0 & 13.3 & 86.7 \\
\hline
\end{tabular}

indices $(2019=100)$

Source: [19]

The average length of tourist stay in Croatia in 2020 was 5.83 days (domestic: 3.72, foreign: 6.28 days). In the year before 2019, the average length of stay of tourists in Croatia was smaller, 4.7. In the last five years (since 2015) the number of tourist arrivals and tourist overnight stays were the lowest in 2020, but the average length of tourist stay in 2020 was the longest. The COVID-19 pandemic had a negative impact on the number of tourist arrivals and overnight stays, but tourists who decided to travel stayed longer in the destination. All counties in Croatia recorded significantly decrease in the number of tourist arrivals and overnight stays. The most significant decrease was recorded in coastal counties because these counties recorded the biggest number of arrivals and overnight stays before the COVID-19 pandemic. Because of that, the COVID-19 pandemic had the most negative impact on the coastal counties (Dubrovačko-Neretvanska County achieved $79.66 \%$ less of tourist arrivals, Istarska County $61.26 \%$, Zadarska county $54.35 \%$, Primorsko-Goranska County 55.38\%). City of Zagreb County, where the capital of Croatia is situated, achieved $76.45 \%$ less of tourist arrivals, so it might be assumed that tourists preferred destinations in the nature that have smaller number of tourists because of the COVID-19 pandemic [19].

Official data further pointed out that tourist arrivals in Serbia also decreased suddenly in 2020, as a consequence of the COVID-19 pandemic (Tables 4 and 6). Compared to 2019, Statistical Office of the Republic of Serbia showed the following results:

- The most affected months were April and May ${ }^{2}$ (Table 6), the same as around the globe (Table 3 and 4). Equal situation is with overnight stays.

- Decrease in tourist arrivals in Serbia (Table 6): 50.7\% (25.4\% of domestic, $75.9 \%$ of foreign tourists);

\footnotetext{
${ }^{2}$ The first case of the COVID-19 in Serbia was registered on March 6, 2020 [22].
} 
- Decrease in tourist overnight stays in Serbia (Table 6): 38.4\% (18.6\% of domestic, $68.5 \%$ of foreign tourists) [21].

Table 6: Tourists arrivals and overnight stays: domestic and foreign - annual data.

\begin{tabular}{|c|c|c|c|c|c|c|c|c|}
\hline \multirow[t]{2}{*}{ Year } & \multicolumn{6}{|c|}{ Tourists arrivals } & \multicolumn{2}{|c|}{$\begin{array}{l}\text { Participation in the } \\
\text { total number of } \\
\text { arrivals in Serbia } \\
\text { (in \%) }\end{array}$} \\
\hline & Total & Index* & Domestic & Index* & Foreign & Index* & Domestic & Foreign \\
\hline 2016 & $2,753,591$ & 113.0 & $1,472,165$ & 112.8 & $1,281,426$ & 113.2 & 53.5 & 46.5 \\
\hline 2017 & $3,085,866$ & 112.1 & $1,588,693$ & 107.9 & $1,497,173$ & 116.8 & 51.5 & 48.5 \\
\hline 2018 & $3,430,522$ & 111.2 & $1,720,008$ & 108.3 & $1,710,514$ & 114.2 & 50.1 & 49.9 \\
\hline 2019 & $3,689,983$ & 107.6 & $1,843,432$ & 107.2 & $1,846,551$ & 108.0 & 49.9 & 50.1 \\
\hline 2020 & $1,820,021$ & 49.3 & $1,374,310$ & 74.6 & 445,711 & 24.1 & 75.5 & 24.5 \\
\hline \multirow[t]{2}{*}{ Year } & \multicolumn{6}{|c|}{ Tourists overnight stays } & \multicolumn{2}{|c|}{$\begin{array}{c}\text { Participation in the } \\
\text { total number of } \\
\text { overnight stays in } \\
\text { Serbia (in \%) } \\
\end{array}$} \\
\hline & Total & Index* & Domestic & Index* & Foreign & Index* & Domestic & Foreign \\
\hline 2016 & $7,533,739$ & 113.3 & $4,794,741$ & 113.0 & $2,738,998$ & 113.7 & 63.6 & 36.4 \\
\hline 2017 & $8,325,144$ & 110.5 & $5,150,017$ & 107.4 & $3,175,127$ & 115.9 & 61.9 & 38.1 \\
\hline 2018 & $9,336,103$ & 112.1 & $5,678,235$ & 110.3 & $3,657,868$ & 115.2 & 60.8 & 39.2 \\
\hline 2019 & $10,073,299$ & 107.9 & $6,062,921$ & 106.8 & $4,010,378$ & 109.6 & 60.2 & 39.8 \\
\hline 2020 & $6,201,290$ & 61.6 & $4,936,732$ & 81.4 & $1,264,558$ & 31.5 & 79.6 & 20.4 \\
\hline
\end{tabular}

*indices $(2010=100)$

The average length of tourist's stay in Serbia in 2020 was 3.41 days (domestic: 3.60, foreign: 2.84 days). In the years before, the average length of stay of tourists in Serbia was less than 2.8 days [21]. The reason for that might be found in the forms of tourism, i.e. types of tourist destinations that became the leading ones in 2020 due to the COVID19 pandemic. The specificity of the pandemic put in the foreground the stay of tourists in a non-urban environment, so that vacation in rural households, combined with various forms of active stay in nature, was the dominant choice of domestic guests. Thus, the smallest decrease in the number of tourist arrivals in Serbia in 2020 was recorded within spa and mountain tourist destinations for both, domestic and foreign tourists. Observed by the total number of tourist arrivals, as well as in relation to 2019, in spa destinations there was a decrease of $22 \%$ in 2020 , while recorded decrease in the mountain destination was $17.8 \%$ [21]. Also, in 2020 several spa places recorded over the $100 \%$ of the total tourist arrivals of the previous year. This was the case with Banja Vrdnik, Sokobanja and Ribarska Banja. Some mountains recorded over $100 \%$ of the total tourist arrivals of the previous year as well: Stara planina and Divčibare.

In Belgrade, the capital city of Serbia, number of tourist arrivals in 2020 represents only $26 \%$ of the turnover in the previous year, while this indicator amounts $34.7 \%$ for Novi Sad [21]. It can be assumed that people preferred staying in nature, where they still feel safer in changed conditions, caused by the pandemic. In this regard, it must be added that quarantine measures were strongly implemented in Serbia during April and May 2020 and that people were eager to take some outdoors activities.

During the summer, new conditions abroad, such as lockdown and restrictive measures for entering the other countries, led to development of domestic tourism. In August 2020, 
there were 25.3\% more arrivals of domestic guests in Serbia, comparing to August 2019, while in September there were $8.9 \%$ more domestic guests comparing to the previous September. Similar situation is repeated during the winter season 2020 [21]. For 2021, it is already evident that a large number of people from Serbia will rather choose shorter and weekend trips in the country. Thus, during the first 1.5 months of 2021 , all 100,000 planned vouchers for subsidized vacations in Serbia were distributed for this year [23], [24].

\section{Intentions of the local people in Serbia to travel during the COVID/19 pandemic}

In order to provide more information regarding the tendencies in the intention of Serbian population to travel in 2020, the survey research was conducted. For the purpose of this research, critical points, or more precisely the important events during the COVID-19 pandemic, were defined, as part of the timeline. The research results suggest the following. Before the occurrence of the COVID-19 pandemic in China, majority of the respondents still did not have plans for their travelling $(58.5 \%)$. Similar situation was recorded upon sharing the information regarding the fact that people in China are infected by the COVID-19 virus, as well as on spreading the virus out of the borders of China $(55.5 \%)$. Percentage of the respondents who did not have plans for their travelling slightly decreased in the following period, or more precisely during the period when the virus occurred in Europe (49.3\%), Italy (49.3\%) and Serbia (46.4\%).

On the other hand, number of people who indicated that they already made a reservation of the travel significantly decreased chronologically. More precisely, the highest percentage of those who already made a reservation of their travel was recorded before the occurrence of the COVID-19 pandemic in China (26.8\%), as well as upon sharing the information on infected people in China $(27.1 \%)$. After that and upon spread of the virus to countries that are territorially closer, percentage of the respondents that already made a reservation of the travel significantly decreased, especially upon its occurrence in Serbia $(7.2 \%)$.

Actions, such as cancellation of reservations, significantly increased in line with chronological development of the virus spreading, from $4.9 \%$ of such actions before the occurrence of the CORONA-19 virus in China, to $18.1 \%$ upon the occurrence of the virus in Serbia. Besides concrete reservations, the research results also indicated that there is an increase in the number of people who cancelled each of their planned trips. Recorded percentage of the respondents who undertook this action increased from $7 \%$ before the occurrence of the virus in China to even $27.2 \%$, when the quarantine measures were implemented in Serbia. It is important to indicate that number of respondents who even made a new reservation increased from the period of occurrence of the virus in line with its spreading, from $2.8 \%$ before its occurrence in China to even $11 \%$ upon its occurrence in Italy. Percentage of such actions was slightly lower upon its occurrence in Serbia, but still higher, comparing to the first phases of the pandemic, mainly on the basis of the fact that respondents made reservations for spending their holidays in Serbia.

Respondents who made their new reservation after the phase in which the first case of the COVID-19 virus was registered planned to visit Greece, Montenegro, Turkey and Tara Mountain in Serbia. It was only possible to visit the last two mentioned destinations, having in mind that boundaries of Greece and Montenegro were closed for tourists from Serbia in the main tourism season and even later (Montenegro opened the boundaries with accompanying measures, while borders of Greece are still closed). It is also important to emphasize that majority of the respondents who made a new reservation upon the 
occurrence of the COVID-19 in Italy planned to travel with the close family members, with friends or their partner. On the other hand, only few (three) respondents indicated that they planned to travel with the group of tourists, while one respondent wanted to travel alone. Similar situation was recorded after the phase in which the first case of the COVID-19 was registered in Serbia: they were thinking on visiting Greece, Montenegro, Turkey and Tara Mountain in Serbia as well. Similar situation also was registered in the case of the respondents' plans with whom they want to travel, as in the case when the virus was registered in Italy.

Regarding the last hypothesis, the research results indicated that number of new reservations slightly increased after publishing the encouraging information in media regarding the overall situation with the COVID-19 virus. In such circumstances, percentage of new reservations amounts $11 \%$ and it increased for $3.5 \%$ comparing to the previous phase, while, at the same time, number of cancelled reservations decreased from $23.3 \%$ to $19.9 \%$, also after publishing the positive information in media.

Finally, according to the research results, $8.8 \%$ of the respondents indicated that they already made a reservation before finding a favourable price for travel arrangements due to the circumstances caused by the COVID-19 pandemic, while even $21.3 \%$ of them pointed out that they booked a new trip due to the better prices set by the tourism offer.

\section{Attitudes of the managers employed in tourism sector in Serbia regarding tourism} business during the COVID-19 pandemic

In order to research indicators of tourism business in Serbia during the COVID-19 conditions in more details, interviews with managers from tourism sector were also conducted. Attitudes of all respondents showed that the COVID-19 pandemic affected tourism in their local area. They mainly answered that number of domestic and foreign tourist arrivals decreased in 2020. However, 9.2\% of them said that recorded number of domestic tourists even increased (mostly within rural areas). Majority of the respondents $(82.3 \%)$ implemented certain measures to motivate tourists to come to their local area during the COVID-19 pandemic (Graph 2).

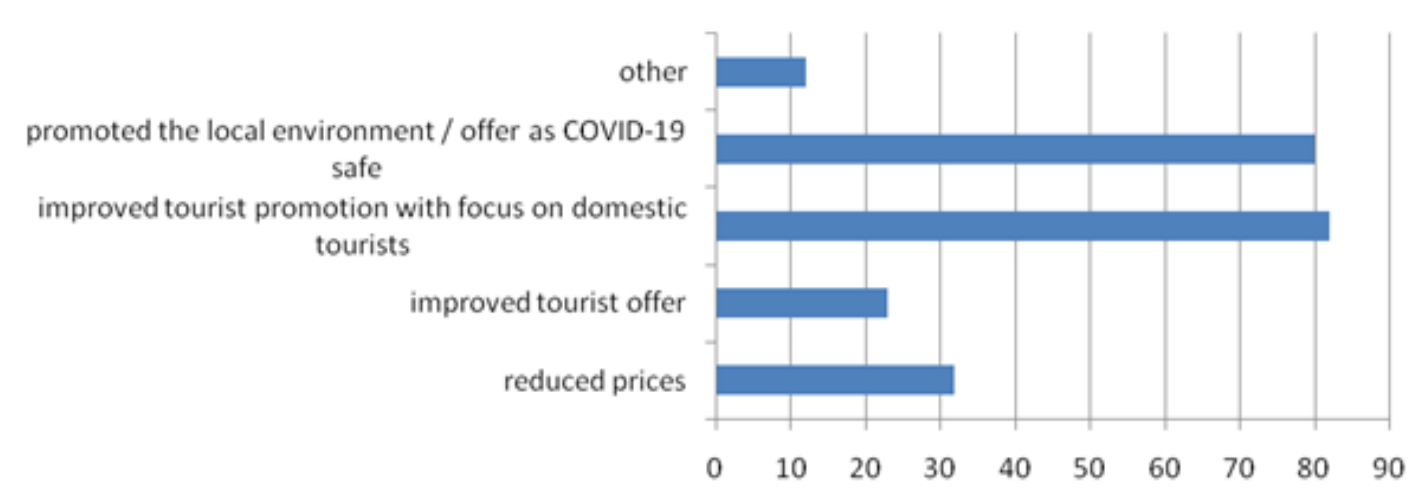

Graph 2: Measures implemented by tourism sector in order to motivate tourists to visit the local destination during the COVID-19 pandemic (in \%)

Further intention was to investigate if there are some changes manifested by tourists regarding specific services and facilities demand. Managers from tourism sector pointed out that nowadays tourists are seeking for the outdoor activities more than before the COVID-19 pandemic. Respondents (73\% of them) also noticed some changes in tourist behavior: caution and fear are manifested; tourists are seeking to visit as isolated places 
in the area as possible; tourists are mostly staying shorter in a common indoor facility (such as restaurant, bar etc.).

Respondents also indicated their attitudes on the manner in which their business unit should prepare their operations for the next tourist season. Even $20.8 \%$ of the respondents still do not have opinion regarding this issue. Minority of them (34.6\%) gave concrete answers, such as: adequate protection measures should be provided (set by national institutions); adding new, primary outdoor activities/facilities; communication with demand should be improved (in order to emphasize their safety during the visit). The rest of them said something like ,The pandemic must be stopped or we will have to learn to live with it".

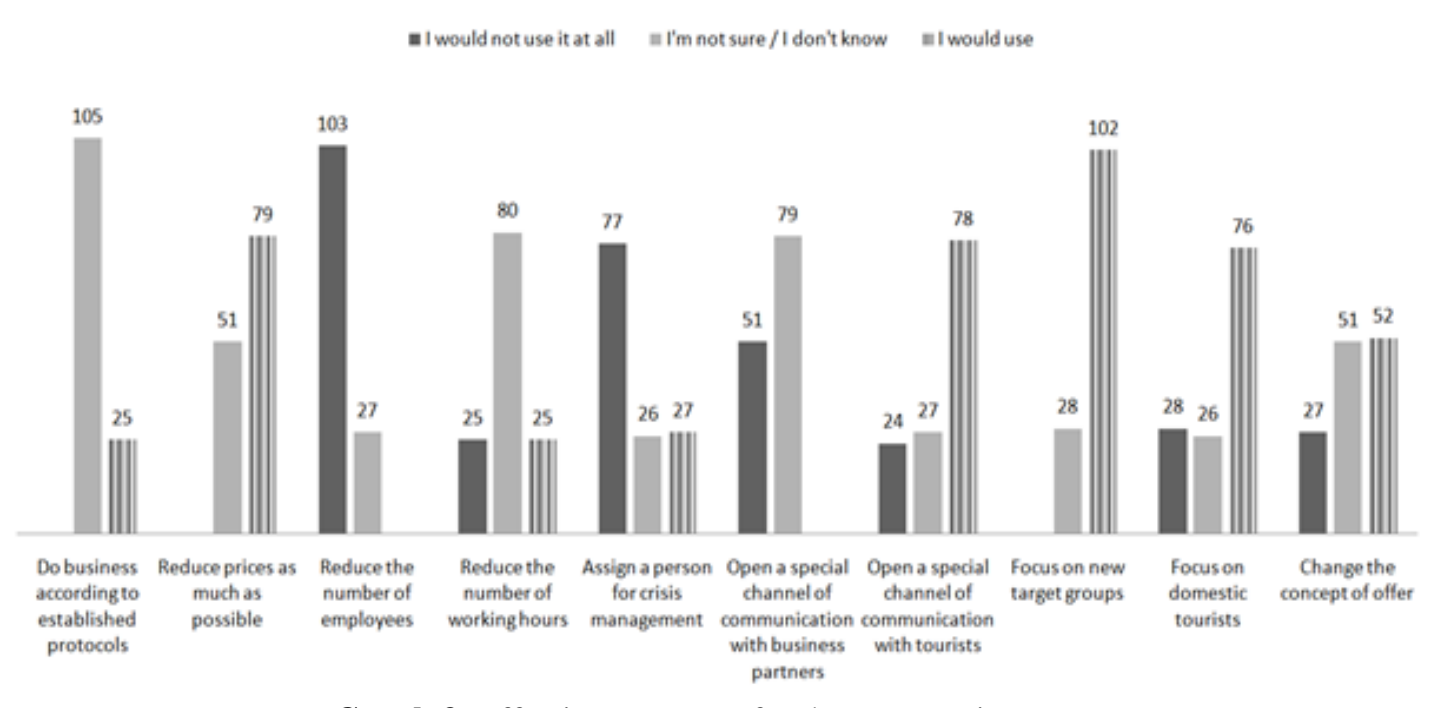

Graph 3: Effective measures for the next tourist season

Finally, respondents were offered the list of the measures that their business unit could undertake. The answers were quite different (Graph 3).

\section{DISCUSSION AND CONCLUSIONS}

This paper analyzes the influence of the COVID-19 pandemic to tourism and accompanying changes it caused for operating in this business sector, in global and national terms, during the 2020. Some patterns of tourist behavior during the crisis have also been observed.

(I) There search results indicated the following facts:

- Tourism sector is very sensitive to global crises, which is evident in the case of the last one, related to the COVID-19 virus. According the findings of the study conducted by Uğur and Akbiyık [15], numerous people around the globe canceled or delayed their travel, almost the same day upon the publication of the news regarding the occurrence and later the spread of the virus, which was followed by discussions regarding the issues of travel assurance.

- Changes in tourist arrivals in 2020 are huge, especially in terms of international tourist arrivals per year/per month. Considering the top 10 tourist destinations, in Croatia and Serbia, as well as worldwide, the most critical months were April and May.

- Destinations around the world that are focused on international tourism, especially those oriented towards business and events, were mainly affected. Unlike cities, rural and coastal areas showed more favorable results [17]. The same situation is in Serbia 
within spa and mountain tourist destinations with recorded decrease in the number of tourist arrivals for both, domestic and foreign tourists, much smaller comparing to cities. In Croatia, COVID-19 pandemic has much more negative impact on developed destinations, in terms of tourism, with the most negative impact on the coastal counties as well as the City of Zagreb County.

- Domestic tourism industries are also affected by different quarantine measures [1]. However, domestic tourism in 2020 gained better results, comparing to international ones. Such trend was also manifested in Serbia. The much smaller decrease in domestic tourist arrivals/overnight stays, comparing to data registered for the foreign ones should not be surprising, considering the fact that people might feel safer by staying at a destination in the home country than abroad. In the home country, most of the people are provided with the necessary health services, while the traffic connection with the home place is easier. Accordingly, the recommendation for summer 2020, given by the COVID-19 crisis national body of Serbia, was for all to stay in the country [22]. Thus, during 2020,300,000 tourist vouchers were distributed, which is the largest number distributed during one year. The most popular tourist destinations in 2020 were Vrnjačka, Ribarska, Gornja Trepča, Prolom, Koviljača, Sijarinska, Sokobanja and Vrujci spa, as well as mountains Zlatibor, Kopaonik, Tara and Divčibare [21].

(II) The next phase of the research was focused on defining the indicators in order to detect the impact of the COVID-19 pandemic on tourism in Serbia, or more precisely on the respondents' intention to travel, or its absence. It might be said that there is a tourist behavior pattern that is following concrete moments on the COVID-19 timeline. Authors defined some events during the COVID-19 pandemic as critical points for making a travel decision. The research results suggested the following:

- Number of people who decided to travel increased chronologically. This finding is in line with general preferences of tourists from Serbia in relation to the time of the year when they make a decision to travel in the main tourist season. In the past decades, they started with such reservations in February. Number of the travel reservations usually continues to grow in months before the summer season, as well as throughout the whole tourist season. In the last few years, the first critical point for showing the intention to travel, by making the reservation for summer trip, is November (during the big discounts for "Black Friday"). The next critical point, with recorded increase in travel reservations, is during the Belgrade Tourism Fair (in February).

- Furthermore, results of the research also pointed to the fact that number of people who indicated that they already made a travel reservation significantly decreased chronologically (from critical point defined as "The first case of the corona virus was registered in China" to critical point defined as "The first case of the corona virus was registered in Serbia"). This finding is in a complete contradiction with tourists' tendencies in the years before the appearance of the COVID-19 virus and the overall global pandemic.

- Actions, such as cancellation of reservations, significantly increased in line with chronological development of the virus spreading, which was expected, given the overall situation related to development of the COVID-19 pandemic.

- Finally, it is important to indicate that number of the respondents who even made a new reservation increased from the period of occurrence of the virus in line with its spreading. It might be supposed that their observation of the pandemic is optimistic, as well as that they expect the end of the crisis in a close future. These respondents 
are even ready to choose the other, safer destination in terms of the COVID-19 pandemic, according to their point of view. It is also important to bear in mind that numerous people established the habit of making a reservation for travel, even in times of the global health and economic crisis.

All three hypotheses, $\mathrm{H} 1-\mathrm{H} 3$, are confirmed, having in mind that, according to the research results, number of travel reservations increased in the later stages of the COVID19 , if we compare this number with statistical indicators registered in the starting phase of the virus occurrence in China. Besides that, the research results also pointed out that number of travel cancelations sharply decreased in the later stages of the COVID-19 pandemic, comparing this number with statistical data from the phase in which the first case of the COVID-19 virus was registered in Serbia. Finally, publishing of the encouraging information in media additionally increased the number of travel reservation, which confirmed the last hypothesis of this research.

To summarize this, there is a pattern of tourist behavior that has been observed according to certain moments in development of the COVID-19 pandemic, which have been identified crucial for travel cancellation.

(III) Another intention was to research the manner in which the managers in tourism sector in Serbia perceive the effects of the COVID-19 pandemic on tourism, particularly from the perspective of their local area or according to their business unit. The research results indicated the following facts:

- All respondents think that the COVID-19 pandemic affected tourism in their local area by decreasing the number of tourist arrivals, both domestic and foreign ones.

- Majority of the respondents implemented certain measures to motivate tourists to come to their local area during the COVID-19 pandemic. They put special attention to the measures oriented towards domestic tourists. They also put effort on promotional activities in order to emphasize the safety of their local area/business unit in new circumstances.

- The expectation was to see more proactive managers when they were asked about plans for the next season, especially having in mind that their jobs have been jeopardized by the pandemic. The research results showed that every fifth respondent did not have an opinion on that issue at all. Every third respondent gave a concrete answer. And finally, almost half of the respondents showed that they will wait for these problems to be solved by the state, vaccines, etc.

- On the other hand, measures for the next season (from the offered list), that respondents found (a) as important, are the following ones: Focusing on new target groups; Opening a special communication channel with tourists; Focusing on domestic tourist; Reducing the prices as much as possible. Similar findings were obtained in the study, conducted by Sánchez-Cañizares et al. [13]. According to their findings, tourists are not ready to pay extra for specific service or product, no matter the fact that increase of the price occurred as a consequence of measures for mitigating the risk related to the pandemic. Furthermore, in the same research, scholars indicated that further marketing activities should be oriented towards specifying the fact that the price of tourism services and products would not increase, by conducting the measures for providing the tourists' safety.

- Measures that respondents found (b) as non-effective are the following ones: Reducing the number of employees; Assigning a person for the crisis management.

- Measures that respondents are not sure about their effectiveness (c) are the following ones: Doing business according to established protocols; Reducing the number of 
working hours; Opening a special communication channel with their business partners.

\section{Contribution to the theory and practice}

The research results of this study are clearly indicating the effects of the pandemic on tourist traffic in 2020, on global and national level. The paper also highlights the forms of tourism, i.e. types of destinations, which will be more or less affected by the mentioned crisis. According to that, authors pointed to the fact that domestic tourism in Serbia might be in significant increase in the next period. Such results could serve as a starting point in defining directions of development of local communities, small and medium enterprises and, finally, the national strategy for tourism development in Serbia.

Besides that, authors developed the set of indicators (defined as critical points) in order to analyse the impact of the COVID-19 pandemic on tourism in Serbia, in relation to the respondents' intention to travel, or to cancel their bookings. In respect to that, experts in the field of tourism will be able to develop appropriate marketing strategy, by considering the indicators that mostly affect tourists' intention to travel. Results of this research might be of use to tourism-based managers and to all other stakeholders involved (state, destination management - national, regional, local). Furthermore, results could find practical implications by the managers from the other sectors that have also been affected by the pandemic. Finally, measures that business unit could undertake to minimize the challenges and risks throughout the COVID-19 pandemic or another crisis, can be useful for building the further strategy of business development.

\section{Acknowledgement}

This paper was founded under the project line ZIP UNIRI of the University of Rijeka, for the project ZIP-UNIRI-116-1-20.

\section{REFERENCES}

[1] ILO. ILO Sectoral Brief: The impact of COVID-19 on the tourism sector. International Labour Organization, 2020. Retrieved from https://www.ilo.org/sector/Resources/publications/WCMS_741468/lang--en/index.htm, Accessed February 2021.

[2] UNWTO. UNWTO World Tourism Barometer May 2020. Special focus on the Impact of COVID-19 (Summary). Retrieved from: https://webunwto.s3.eu-west-1.amazonaws.com/s3fspublic/2020-05/Barometer\%20-\%20May\%202020\%20-\%20Short.pdf. Accessed February 2021.

[3] Marques Santos A., Madrid González C., Haegeman K., \& Rainoldi, A. Behavioural changes in tourism in times of COVID-19: Employment scenarios and policy options. European Commission - JRC Science for Policy Report, pp 1-61, 2020.

[4] UNWTO. COVID - 19 Related Travel Restrictions a Global Review for Tourism - Seventh Report as of 10 September 2020. UNWTO: Sustainable Development of Tourism Department. Retrieved from https://www.unwto.org/news/70-of-destinations-have-lifted-travel-restrictionsbut-global-gap-emerging, Accessed February 2021.

[5] UNWTO. Impact assessment of the COVID-19 outbreak on international tourism. UNWTO, 2020. Retrieved from https://www.unwto.org/impact-assessment-of-the-covid-19-outbreak-oninternational-tourism, accessed January 2021.

[6] https://www.unwto.org/unwto-tourism-recovery-tracker 
[7] Gallego I. \& Font X. Changes in air passenger demand as a result of the COVID-19 crisis: using Big Data to inform tourism policy, Journal of Sustainable Tourism, DOI: 10.1080/09669582.2020.1773476, 2020.

[8] Han H., Lee S., Kim, J.J. \& Ryu H.B. Coronavirus Disease (COVID-19), Traveler Behaviors, and International Tourism Businesses: Impact of the Corporate Social Responsibility (CSR), Knowledge, Psychological Distress, Attitude, and Ascribed Responsibility. Sustainability, 12, 8639. https://doi.org/10.3390/su12208639, 2020.

[9] Higgins-Desbiolles F. Socialising tourism for social and ecological justice after COVID-19, Tourism Geographies, Vol. 22:3, pp 610-623, 2020.

[10] Ioannides D. \& Gyimóthy S. (2020). The COVID-19 crisis as an opportunity for escaping the unsustainable global tourism path, Tourism Geographies, Vol. 22:3,pp 624-632, 2020.

[11] Lamb T.L., Winter S.R., Rice S., Ruskin K.J. \& Vaughn, A. Factors that predict passengers willingness to fly during and after the COVID-19 pandemic. Journal of Air Transport Management, Vol. 89, 101897, https://doi.org/10.1016/j.jairtraman.2020.101897, 2020.

[12] Li Zh., Zhang Sh. , Liu X., Kozak M. \& Wen, J. Seeing the invisible hand: Underlying effects of COVID-19 on tourists' behavioral patterns. Journal of Destination Marketing \& Management Vol. 18, 100502, https://doi.org/10.1016/j.jdmm.2020.100502, 2020.

[13] Sánchez-Cañizares S.M., Cabeza-Ramírez L.J., Muñoz-Fernández M. \& Fuentes-García F.J. Impact of the perceived risk from Covid-19 on intention to travel. Current Issues in Tourism. https://doi.org/10.1080/13683500.2020.1829571, 2020.

[14] Seyfi S., Hall C. M., \& Shabani B. COVID-19 and international travel restrictions: The geopolitics of health and tourism. Tourism Geographies. DOI:10.1080/14616688.2020.1833972, 2020.

[15] Uğur N.G. \& Akbıyık, A. Impacts of COVID-19 on global tourism industry: A cross-regional comparison. Tourism Management Perspectives Vol. 36, 100744. https://doi.org/10.1016/j.tmp.2020.100744, 2020.

[16] Statista. Impacto del coronavirus en el sector turísticoen España. Datosestadísticos. [Coronavirus impact in the tourism sector in Spain. Statistical Data]. https://es.statista.com/temas/6510/impacto-del-coronavirus-en-el-sector-turistico-en-espana/, 2020.

[17] OECD. OECD Policy Responses to Coronavirus (COVID-19): Rebuilding tourism for the future: COVID-19 policy responses and recovery from http://www.oecd.org/coronavirus/policyresponses/rebuilding-tourism-for-the-future-covid-19-policy-responses-and-recovery-bced9859/ Accessed January 2021).

[18] https://data.stat.gov.rs/Home/Result/220203?languageCode=en-US (Accessed January 2021)

[19] https://mint.gov.hr/pristup-informacijama/dokumenti-80/statistike/11514 (Accessed February 2021)

[20] https://koronavirus.hr/ (Accessed February 2021)

[21] SORS (2021). Informacija o turističkom prometu u Srbiji za period januar-decembar 2020.

Statistical Office of The Republic Of Serbia: Belgrade (Retrieved from https://mtt.gov.rs/download/Turisti\%C4\%8Dki\%20promet\%20-

\%20DECEMBAR\%202020.docx, accessed February 2021).

[22] https://covid19.rs/ (Accessed January 2021)

[23] https://mtt.gov.rs/vauceri-za-odmor-u-srbiji/ (Accessed February 2021)

[24] http://istnews.com/224-novosti/\#wb_LayoutGrid21 (Accessed February 2021) 